Point of View

\title{
Quantifying soil carbon stocks and greenhouse gas fluxes in the sugarcane agrosystem: point of view
}

\author{
Carlos Eduardo Pellegrino Cerri ${ }^{1 *}$, Marcelo Valadares Galdos², João Luís Nunes Carvalho², Brigitte Josefine Feigl ${ }^{3}$, Carlos \\ Clemente Cerri ${ }^{3}$
}

IUSP/ESALQ - Depto. de Ciência do Solo, Av. Pádua Dias 11, C.P. 09 - 13418-900 - Piracicaba, SP - Brasil. ${ }^{2}$ CNPEM/CTBE - Laboratório Nacional de Ciência e Tecnologia do Bioetanol, Polo II de Alta Tecnologia, R. Giuseppe Máximo Scolfaro, 10.000 - 13083-970 Campinas, SP - Brasil.

3USP/CENA, Av. Centenário, 303 - 13400-970 -

Piracicaba, SP - Brasil.

*Corresponding author <cepcerri@usp.br>

Edited by: Paulo Sergio Graziano Magalhães
ABSTRACT: Strategies to mitigate climate change through the use of biofuels (such as ethanol) are associated not only to the increase in the amount of $C$ stored in soils but also to the reduction of GHG emissions to the atmosphere. This report mainly aimed to propose appropriate methodologies for the determinations of soil organic carbon stocks and greenhouse gas fluxes in agricultural phase of the sugarcane production. Therefore, the text is a piece of contribution that may help to obtain data not only on soil carbon stocks but also on greenhouse gas emissions in order to provide an accurate life cycle assessment for the ethanol. Given that the greenhouse gas value is the primary measure of biofuel product quality, biorefiners that can show a higher offset of their product will have an advantage in the market place. Keywords: soil organic matter, global warming, nitrous oxide, ethanol

Received September 11, 2012

Accepted February 11, 2013

\section{Introduction}

One of the most challenging societal missions of the coming decades is meeting the increasing demand for natural resources driven by a dramatic growth of the human population from currently six to around 10 billion people in 2050 (Davidson et al., 2012). Vis-a-vis the depleting fossil fuel resources the use of biomass for renewable energy production has already become an important issue for highly industrialized countries (Foley et al., 2011) as well as for emergent countries such as Brazil.

Although Brazil has no mandatory commitment within the framework of the United Nations Framework Convention on Climate Change (UNFCCC), there is a growing pressure to limit or reduce greenhouse gas emissions on national scale (Beddington et al., 2012). Increasing efficiencies in energy use is one option, but the scope of this measure is limited in countries like Brazil with their steadily growing economies and energy demand. Thus, meeting the UNFCCC target also has to include the substitution of fossil fuel energy by renewable energy sources such as bioenergy. Additionally, sharply increasing fossil fuel prices and increasing uncertainties on the energy market in recent years have strongly promoted the use of biomass for energy purposes and as resource in industrial processes. Meanwhile, these biomass sources are included in almost all energy scenarios as an innovative strategy for industrialized as well as for developing countries (Hoogwijk et al., 2001). Biomass used for fuel can be derived from different sources, one of them being ethanol production via fermentation of biomass. Sugarcane (Saccharum spp.) as a C4 plant is highly efficient in turning solar radiation into biomass. It is currently produced commercially and used for ethanol production in over 70 countries, with Brazil being the main producer with a share of $33 \%$ of the global production (FAOSTAT, 2012).

The current trend is for growth in the biofuel sector, mainly due to geopolitical, economic and environmental issues further promoting the use of ethanol as alternative to fossil fuel. However, up to now it is not well understood how large scale intensive production of biomass for energy purposes and/or changes in agricultural management will feed back on the biogeochemical cycles of carbon $(\mathrm{C})$, nitrogen $(\mathrm{N})$ and water. For instance, possible negative effects include enhanced greenhouse gas (GHG) emissions, especially of the potent $\mathrm{N}_{2} \mathrm{O}$ (with a global warming potential of 298 as compared to $\mathrm{CO}_{2}$ ), emitted from synthetic fertilizer application. On the other hand, positive environmental consequences might result, if soil $\mathrm{C}$ and $\mathrm{N}$ stocks could be increased due to adaptation of agricultural management such as improved treatment of crop residues. Thus, biofuel production is an important component in any sustainable regional management strategy, requiring the balancing of ecological and economic demands.

In Brazil, burning the dry leaves and tops in order to facilitate the sugarcane harvesting and transportation of the stalks is still a common practice. Burning plant residues causes emissions of GHG such as $\mathrm{CO}_{2}, \mathrm{CH}_{4}$ and $\mathrm{N}_{2} \mathrm{O}$, besides the release of charcoal particles into the atmosphere, which could reportedly cause health problems to the surrounding populations (Cançado, 2006). Due to a combination of pressure from changes in the 
public opinion and economical reasons, sugarcane is changing from a burned into an unburned system. Mechanical harvesters have been developed that can take the stalk and leave the residues on the field, forming mulch, in a system called green cane management. It is expected that $80 \%$ of the cane harvested in the main producing regions in Brazil will be harvested without burning by 2014 (Macedo and Nogueira, 2004; Galdos et al., 2010).

The conversion from burning sugarcane to green management of sugarcane will have impacts on the biogeochemical cycling of $\mathrm{C}$ and $\mathrm{N}$ in the plant soil system. Instead of burning, "green" management will result in the deposition of large amounts of plant litter on the soil surface after harvest, ranging from 10 to 20 tons of dry matter per hectare, which will have impacts on the whole production process of sugarcane, influencing yields, fertilizer management and application, soil erosion, soil organic matter (SOM) dynamics as well as GHG emissions $\left(\mathrm{CO}_{2}, \mathrm{~N}_{2} \mathrm{O}, \mathrm{CH}_{4}\right)$.

From a GHG perspective, the conservation of sugarcane residues prevents emissions from the burning process, may promote $\mathrm{C}$ sequestration in soils and fixes $\mathrm{N}$ during the decomposition process replacing the need for, and GHG emissions from, fossil fuel based nitrogen fertilizer sources. Measurements of soil C and $\mathrm{N}$ stocks and associated greenhouse gas emissions from the burned and unburned sugarcane systems and in the sugarcane expansion areas are still scarce.

Therefore, the main objective of this study was to propose appropriate methodologies for the determinations of soil organic C and GHG fluxes in sugarcane production. The proposition of appropriate methodologies is important since strategies to mitigate climate change through the use of biofuels (such as ethanol) are associated not only to the increase in the amount of $\mathrm{C}$ stored in soils but also to the reduction of GHG emissions to the atmosphere.

\section{Soil carbon}

Soil organic matter is an important pool in the C cycle, comprising $1500 \mathrm{Pg}$ of $\mathrm{C}$ in the first meter of soil, of which one quarter is in tropical soils (Crasswell and Lefroy, 2001). The terrestrial biosphere, which also includes $600 \mathrm{Pg}$ in vegetation, represents three times as much $\mathrm{C}$ as present in the atmosphere. Therefore, changes in SOM have a significant impact on the global C cycle (Schmidt et al., 2011).

Soil C stock dynamics in agricultural systems is conditioned by factors such as climate, soil texture, topography, type and amount of organic material added as soil and surface litter, and the degree of disturbance by tillage operations. Soil $\mathrm{C}$ stock changes are usually not detectable in the short term (days and months), but in the time frame of years (Minasny et al., 2012). The effect of management practices and land use change on soil $\mathrm{C}$ on a specific site can be detected through two main ways. In the first approach, measurements are taken in the same area at different moments in time, in long term experiments. A second approach, a chronosequence, is possible when there is a set of areas with similar topography, soil type and soil texture, with different land uses and periods of conversion. A reference area is selected, which is usually native vegetation or the previous land use site. Then, areas representing the main land uses with different times since conversion are sampled, providing an estimate of the temporal changes in soil $\mathrm{C}$.

Two examples of chronosequences are described in Figure 1. In the first example, a native vegetation area was converted to sugarcane with pre-harvested burning, which caused a decline in soil C stocks. After 20 years of burning, there was a change in harvest system to unburned sugarcane, with maintenance of crop residues on the soil, which led to an increase in soil C stocks. Areas with 10 and 20 years of unburned management were used to estimate this increase in soil $\mathrm{C}$ with time. In the second example, degraded pastures, with low baseline soil C stocks, were converted into unburned sugarcane, and there was a steady increase in soil C stocks, demonstrated by sampling in fields under unburned sugarcane for 1, 10 and 20 years. The main advantage of the chronosequence methodology is that it makes it possible to concentrate the sampling in one occasion, instead of waiting several years to resample.

\section{Sampling methodology}

Soil C stocks should be measured using sampling methodology compatible with the 2006 IPCC Guidelines for National Greenhouse Gas Inventories - volume 4, as well as the ISO 10381-1:2002a, ISO 10381-2:2002b and ISO 10381-4:2003 standards.

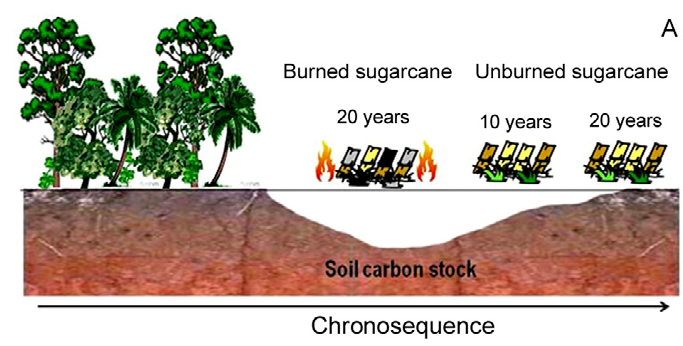

B

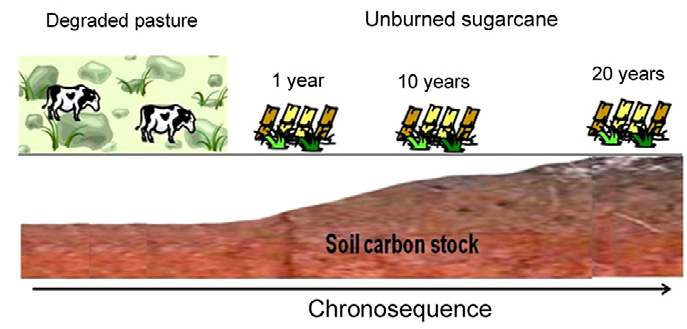

Figure 1 - Examples of chronosequences of A) native vegetation converted into burned sugarcane, which is replaced by unburned sugarcane and B) degraded pasture converted into unburned sugarcane. 


\section{Position and density of sampling points}

In the characterization of the soil $\mathrm{C}$ content of an area, it is generally not possible to examine the whole and it is therefore necessary to take samples. The soil samples collected must be as representative as possible of the whole area being characterized. The pre-selection of the area where samples will be taken could be made using soil maps, land use maps, aerial photographs, satellite images and interviews about land use history. In parallel to the desk-top work, site visits can be used to evaluate the exact location of the sampling points. The grid sampling scheme provides a good coverage of the sampled area, while allowing for future identification of the area for re-sampling purposes. Each sampling area should be georeferenced using a GPS device, and the sampling pits should be plotted on a map of the area. A $3 \times 3$ grid totaling nine pits, $50 \mathrm{~m}$ apart from each other, covering an area of one hectare, is adequate for agricultural areas.

\section{Sampling depth}

The Intergovernmental Panel on Climate Change soil C method (IPCC, 2006) considers at least the top 0.3 $\mathrm{m}$ of the profile and adapt according to a given situation. However, several authors have emphasized the need to investigate soil $\mathrm{C}$ stocks at deeper layers when assessing the impact of management changes in sugarcane, preferably down to one meter (Resende et al., 2006), from various depth intervals since soil $\mathrm{C}$ has not a linear behavior along soil profile. Samples could be sampled from the following soil layers: $0-0.1,0.1-0.2,0.2-0.3,0.4-0.5,0.7$ 0.8 and $0.9-1.0 \mathrm{~m}$ for three out of nine pits and $0-0.1,0.1$ $0.2,0.2-0.3 \mathrm{~m}$ in the other 6 pits (Figure 2). Regression models or pedotransfer functions (Benites et al., 2007) can be used to estimate bulk density for the layers that were not sampled (i.e., 0.3-0.4, 0.5-0.6, 0.6-0.7, 0.8-0.9 $\mathrm{m})$. In the three deeper soil pits (till $1.0 \mathrm{~m}$ ) soil bulk density should be determined and soil $\mathrm{C}$ content should be analyzed from all the 36 samples per site.

\section{Sampling procedures}

Once the sampling grid is established and marked on the field, soil sampling will consist in two steps: i) gaining access to the point of sampling (removing plant litter and digging the trenches down to the desired depth of sampling), and ii) taking the soil sample. The bulk of surface litter must be removed manually with care. The fine litter closer to the soil surface must be lightly dusted off, avoiding the removal of soil particles on the surface layer. The deeper trenches will measure 1.5 (depth) $\times$ 1.5 (length) $\times 1.0$ (width) $\mathrm{m}$, and the smaller trenches will measure $0.4 \times 0.4 \times 0.4 \mathrm{~m}$.

Once the pits are dug, soil samples will be taken in $0.1 \mathrm{~m}$ increments using a coring cylinder with a well known volume. In order to determine soil bulk density, some of the samples should be undisturbed, preserving soil structure. When sampling in the sugarcane fields, samples should be taken both in the rows and the inter-

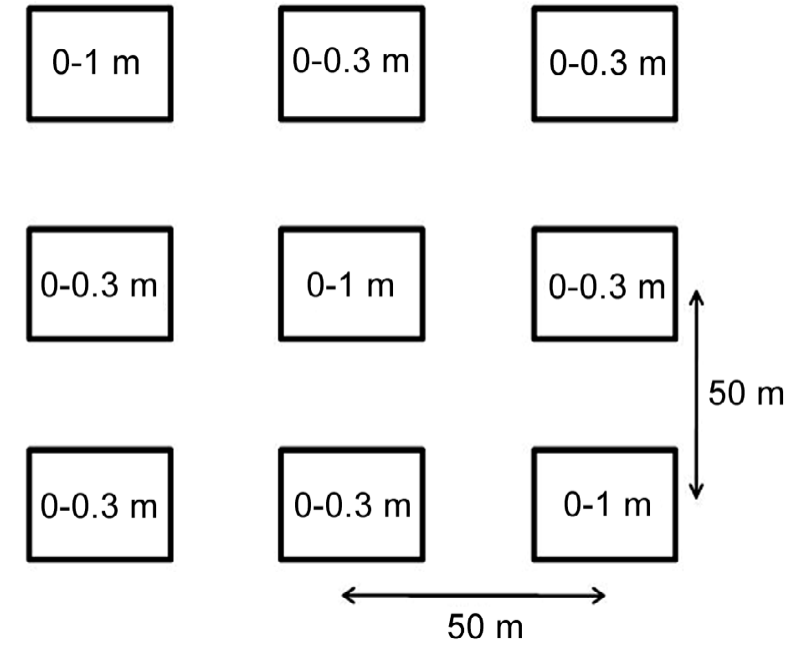

Figure 2 - Sampling design for soil carbon and bulk density determinations. The nine trenches cover an area of a hectare. From six trenches samples are taken from the layer 0-0.1, 0.1-0.2 and $0.2-0.3 \mathrm{~m}$ depths. From the remaining three trenches, soil is sampled from $0-0.1,0.1-0.2,0.2-0.3,0.4-0.5,0.7-0.8$ and 0.9 $1.0 \mathrm{~m}$ layers. Thus a total of 36 samples are collected from each evaluated site.

rows, in order to detect possible spatial differences related to traffic of machines, tillage operations and root C turnover.

The soil samples should be conditioned in plastic bags previously labeled and taken to the laboratory for sample preparation. Samples will be air dried, homogenized and sieved in a $2 \mathrm{~mm}$ screen. The fraction greater than $2 \mathrm{~mm}$ needs to be weighted to calculate the adequate $\mathrm{C}$ stock for the given soil layer; although this fraction is considered as C-free.

\section{Carbon content determination}

Subsamples of the soil sieved in $2 \mathrm{~mm}$ screens should be ground and sieved at 60 meshes for $\mathrm{C}$ determination by dry combustion (Nelson and Sommers, 1996). Total C should be determined by dry combustion using an elemental analyzer (furnace at $1100-1500{ }^{\circ} \mathrm{C}$ in pure oxygen). This method provides total $\mathrm{C}$, which is composed of inorganic (from carbonates) and organic C. In most Brazilian soils, the inorganic $\mathrm{C}$ content is small; therefore the total $\mathrm{C}$ content determined by dry combustion is mostly comprised of organic fraction. However, in soils with high carbonate content, the organic $\mathrm{C}$ determination can be done by wet oxidation with dichromate (Walkley and Black, 1934) or by dry combustion after a preliminary carbonates removal with acid, typically $\mathrm{HCl}$ $0.1 \mathrm{M}$ (Schumacher, 2002).

\section{Calculation of carbon stocks}

Several studies that focus on SOM dynamics under different soil and residue management systems present 
the results in $\mathrm{C}$ content, not in stocks. Nevertheless, the concept of stocks is more useful than $\mathrm{C}$ content, since it is a measurement of the mass in a specific volume of soil. For each sampled soil layer the calculations for $\mathrm{C}$ stocks $\left(t \mathrm{ha}^{-1}\right)$ will be carried out by multiplying the $\mathrm{C}$ content $\left(\mathrm{g} \mathrm{kg}^{-1}\right)$ by the soil bulk density $\left(\mathrm{g} \mathrm{cm}^{-3}\right)$ and by the layer thickness $(\mathrm{cm})$.

\section{Correction for the same soil mass}

Since C stock is also a function of soil bulk density, factors such as machine traffic and soil tillage, which affect soil density, could influence the results. By correcting the density of all sites to a reference area, the stock comparison will be done considering the same mass of soil (Ellert and Bettany, 1996; Moraes et al., 1996). Carbon stocks in the areas being evaluated should be calculated in an equivalent depth basis, i.e., considering the depth that contains the same mass of soil as the corresponding layer of the reference area. The reference areas is generally the previous land use (e.g., pasture or annual crop site) or a native vegetation site, depending on the land use history of the evaluated area. Another possible approach is to use the mass coordinate system /Gifford and Roderick, 2003; McBratney and Minasny, 2010).

\section{Greenhouse gases emissions}

Greenhouse gases emissions to the atmosphere and their contribution to climate change have attracted worldwide attention. Concentrations of atmospheric GHG, such as $\mathrm{CO}_{2}, \mathrm{CH}_{4}$, and $\mathrm{N}_{2} \mathrm{O}$, which can alter the earth's climate, have risen substantially during the last decades. This has resulted in a need for process based understanding of the main factors influencing the exchange of these gases between the soil and atmosphere.

The $\mathrm{CO}_{2}$ concentration increased of 280 to 390 ppm (parts per million) in last decades, and actually increase the rate of 2.2 ppm year ${ }^{-1}$ (IPCC, 2007a). According to Forster et al. (2007), the first 50 ppm was achieved in more than 200 years after Industrial Revolution, while the remaining 50 ppm was accumulated in 30 years. In the period from 1960 to 2005, the increase in $\mathrm{CO}_{2}$ emissions was 1.4 ppm year ${ }^{-1}$. The increase in $\mathrm{CO}_{2}$ emissions is due to a combination of factors such as deforestation, biomass burning, use of fossil fuels, cement production, tillage operations and lime application in agriculture (Denman et al., 2007). Although $\mathrm{CO}_{2}$ fluxes from the soil can be intensified in agricultural areas, this gas is not considered in the global balance of GHG. According to the Intergovernmental Panel on Climate Change (IPCC, $2007 \mathrm{a}$, b) $\mathrm{CO}_{2}$ fluxes are measured by mass balance; $\mathrm{CO}_{2}$ is assimilated through photosynthesis in the next sugarcane cycle and, thus, does not contribute towards an increase in the GHG concentrations in the atmosphere.

Emissions of the non- $\mathrm{CO}_{2}$ greenhouse gases, $\mathrm{CH}_{4}$ and $\mathrm{N}_{2} \mathrm{O}$, also have significant impacts on global warming. Those of $\mathrm{CH}_{4}$ are estimated to account for $18 \%$ of greenhouse warming (Denman et al., 2007). The concentration of $\mathrm{CH}_{4}$ in the atmosphere increased $150 \%$ between the period of 1750 and 2000 from 700 to $1745 \mathrm{ppb}$, and has more recently increased at a rate of 7 ppb year $^{-1}$ (IPCC, 2007a). Despite the short residence time in the atmosphere (12 years), $\mathrm{CH}_{4}$ has global warming potential of 25 times more than $\mathrm{CO}_{2}$ (IPCC, 2007b). Landscape sources of $\mathrm{CH}_{4}$ are estimated to contribute $86 \%$ of all $\mathrm{CH}_{4}$ emissions, some $58 \%$ coming from anthropogenic sources: landfills and wastes, ruminants, rice growing and biomass burning. The remainder comes from natural sources, as such wetlands and termites (IPCC, 2007b). Methane emissions from cultivated soils in tropical conditions are usually very low or even negative (Mer and Roger, 2001) thus, not contributing to the GHG balance and therefore will not be emphasized in the present work.

$\mathrm{N}_{2} \mathrm{O}$ is a potent GHG contributing to global warming and atmospheric ozone depletion. Despite its low concentration of 12 to $319 \mathrm{ppb}$ (IPCC, 2007a), it is the fourth largest contributor to enhance warming (Denman et al., 2007). The $\mathrm{N}_{2} \mathrm{O}$ concentration in the atmosphere is substantially lower than $\mathrm{CO}_{2}$. However, its persistence in the atmosphere, when considered over a 100 year period, as well as its absorptivity for infrared radiation, lead to a global warming potential 298 times higher than $\mathrm{CO}_{2}$, per unit of weight. Atmospheric $\mathrm{N}_{2} \mathrm{O}$ is annually increasing at a rate of $0.2-0.3 \%$, and this increase is thought to be due to anthropogenic emissions (IPCC, 2007b).

\section{$\mathrm{N}_{2} \mathrm{O}$ emissions in agricultural soils}

Globally, it is estimated that agricultural soils emit approximately $4.2 \mathrm{Tg} \mathrm{N}_{2} \mathrm{O} \mathrm{yr}^{-1}$ or about $50 \%$ of global anthropogenic $\mathrm{N}_{2} \mathrm{O}$ (Mosier et al., 1998). $\mathrm{N}_{2} \mathrm{O}$ is mainly generated by mineral $\mathrm{N}$ originating from applied $\mathrm{N}$ fertilizer, mineralization of SOM and biologically fixed $\mathrm{N}_{2}$. Nitrous oxide is also indirectly emitted from additions of $\mathrm{N}$ to soils and waters through conversion of $\mathrm{N}$ into gaseous ammonia $\left(\mathrm{NH}_{3}^{-}\right)$and oxides of $\mathrm{N}$, which are then returned to soil in the form of ammonium $\left(\mathrm{NH}_{4}{ }^{+}\right)$, nitric acid $\left(\mathrm{HNO}_{3}\right)$, and oxides of N. Surface runoff and leaching of applied $\mathrm{N}$ into ground water and surface waters can also result in indirect emissions of $\mathrm{N}_{2} \mathrm{O}$ to the atmosphere (IPCC, 2007).

Nitrous oxide is produced mainly through aerobic autotrophic nitrification (Kowalchuck and Stephen, 2001), anaerobic heterotrophic denitrification (Knowles, 1982) and nitrifier denitrification (Wrage et al., 2001; Ma et al., 2007). The magnitude of fluxes between soil and atmosphere depends largely on soil temperature, soil water content, $\mathrm{O}_{2}$ availability, $\mathrm{N}$ substrate availability (nitrate and ammonium), and organic C. In addition, these regulators are strongly influenced by weather, vegetation, soil properties (bulk density, organic matter, $\mathrm{pH}$ and clay content), and land management (Dobbie and Smith, 2003). The soil-atmosphere exchange of $\mathrm{N}_{2} \mathrm{O}$ depends on complex interactions between soil properties, soil micro-organisms, climatic factors, and agricultural practices (Saggar et al., 2009). Moreover, due to the mentioned complexity, there is an increasing debate concerning $\mathrm{N}_{2} \mathrm{O}$ sink by soils (Chapuis-Lardy et al., 2007). 


\section{Measurements of $\mathrm{N}_{2} \mathrm{O}$}

The last decade has seen greatly increased efforts worldwide into methodologies for measuring exchanges of $\mathrm{N}_{2} \mathrm{O}$ between soil and atmosphere. Measurements of $\mathrm{N}_{2} \mathrm{O}$ are challenging because of the low ambient concentrations. The accurate assessment of GHG fluxes from ecosystems, therefore, is experimentally challenging. Knowledge of the factors behind the systematic variation among different ecosystems and across seasons is needed.

There are several methods for $\mathrm{N}_{2} \mathrm{O}$ sampling, and each has advantages and disadvantages. Each sampling GHG technique has its niche (Denmead et al., 2008). A number of methods and approaches including the simple and widely used enclosure methods (static chambers), and diffuse source micrometeorological methods with various degrees of complexity (eddy covariance, flux gradient, eddy accumulation, and backward Lagrangian dispersion) can be used to determine the soil $\mathrm{N}_{2} \mathrm{O}$ flux (Saggar et al., 2010).

The most commonly used technique for soil $\mathrm{N}_{2} \mathrm{O}$ sampling is static chambers (closed and open). A commonly described disadvantage of the static chamber method is that they cover a small soil surface area and many chambers are required for a representative emissions estimate. On the other hand, methods more complex have advantage of providing continuous measurement and achieving spatial integration of fluxes, but they are generally expensive (Saggar et al., 2010) and difficult to maintain.

Statics chambers are an intrusive gas flux measuring method and their deployment on the soil surface often modifies the flux that it is intended to measure. Con- sequently, several precautions need to be taken to avoid biased flux estimates when using chambers (Rochette and Eriksen-Hamel, 2008).

\section{Criteria to evaluate chamber methodology in stud- ies on $\mathrm{N}_{2} \mathrm{O}$}

Considerable variation can be observed in the chamber methodology used to measure soil $\mathrm{N}_{2} \mathrm{O}$ fluxes in recent literature (Rochette and Eriksen-Hamel, 2008). These authors performed a literature review to evaluate criteria were determined for assessing the quality of soil $\mathrm{N}_{2} \mathrm{O}$ flux measurements made using chambers. The selection of criteria was based on recommendations made in previous reviews of chamber techniques (Hutchinson and Livingston, 2002; Livingston and Hutchinson, 1995; Holland et al., 1999; Smith and Conen, 2004; Rochette and Hutchinson, 2005; Rochette and Bertrand, 2007). Below are listed some criteria that must be evaluated to verify the quality of the measurements of $\mathrm{N}_{2} \mathrm{O}$ fluxes using chambers (Table 1).

Regarding the type of chamber, the $\mathrm{N}_{2} \mathrm{O}$ flux measurements should be made using a two-piece (base and chamber). It is recommended that the chambers have a suitable thermal insulation and are made of material that does not result in an increase in the internal temperature. Chamber height affects the quality of chamber measurement in several ways. For better scaling of the size of the chamber is necessary to evaluate the incubation time. Large chambers and short incubation time results in underestimated $\mathrm{N}_{2} \mathrm{O}$ flux and small chambers and long incubation time overestimate the results. In order to perform a better evaluation of the GHG flux in sugarcane fields, it is recommended a rectangular cham-

Table 1 - Score assigned to each characteristic of non-flow-through, non-steady-state chamber design and deployment. The score of each characteristic to the quality of $\mathrm{N}_{2} \mathrm{O}$ emission data is based on estimated impact of each characteristic on the measurement error. Adapted from Rochette and Eriksen-Hamel (2008).

\begin{tabular}{|c|c|c|c|c|}
\hline \multicolumn{2}{|c|}{ Chamber characteristics } & Unit & Poor & Good \\
\hline & & \multicolumn{3}{|c|}{ Binary and non-numerical characteristics } \\
\hline \multicolumn{2}{|l|}{ Type of chamber } & & push-in & base and chamber \\
\hline \multicolumn{2}{|l|}{ Insulation } & & No & yes \\
\hline \multicolumn{2}{|l|}{ Vent } & & No & yes \\
\hline \multicolumn{2}{|c|}{ Pressurized sample (fixed-volume container only) } & & No & yes \\
\hline \multicolumn{2}{|c|}{ Quality control sample } & & No & yes \\
\hline \multicolumn{2}{|c|}{ Time zero sample taken } & & No & yes \\
\hline \multicolumn{2}{|c|}{ Temperature corrections } & & No & yes \\
\hline \multirow{2}{*}{\multicolumn{2}{|c|}{ Type of sample vial }} & & plastic and glass syringe & $\begin{array}{c}\text { all others vials, exetainers, and } \\
\text { vacutainers }\end{array}$ \\
\hline & & & Numerical characteris & \\
\hline \multicolumn{2}{|c|}{ Height oh chamber } & $\mathrm{m} \mathrm{h}^{-1}$ & $<0.20$ & $\geq 0.20$ \\
\hline \multicolumn{2}{|c|}{ Chamber base insertion* } & $\mathrm{m}$ & $<0.05$ or $>0.10$ & $0.05-0.10$ \\
\hline \multicolumn{2}{|c|}{ Duration of incubation* } & Min & $\geq 40$ & $<40$ \\
\hline \multicolumn{2}{|c|}{ Number of samples } & no & $\leq 2$ & $\geq 3$ \\
\hline \multirow{3}{*}{$\begin{array}{l}\text { Duration of sample } \\
\text { storage }\end{array}$} & plastic syringe & & $>2$ & $\leq 2$ \\
\hline & glass syringe & Day & $>2$ & $\leq 2$ \\
\hline & other & & $>45$ & $\leq 45$ \\
\hline
\end{tabular}

*Estimated by the authors 
ber with $0.70 \times 0.45 \mathrm{~m}$ size. These dimensions are associated with sugarcane row-space, which in most of the areas is $1.5 \mathrm{~m}$ between planting rows. It is recommended the use of fans inside the chamber in order to homogenize the air, especially in large chambers.

To obtain representative fluxes of $\mathrm{N}_{2} \mathrm{O}$ in sugarcane areas, at least five static chambers should be used. The base should be inserted into the soil one day before the beginning of gas sampling. Inserting the base at $0.05-$ $0.10 \mathrm{~m}$ of soil depth is recommended. Introducing the base less than $0.05 \mathrm{~m}$ depth can result in gas exchange between the inside and outside the chamber and deeper than $0.1 \mathrm{~m}$ may modify the water movement in the soil inside the chamber and consequently affect $\mathrm{N}_{2} \mathrm{O}$ fluxes.

The $\mathrm{N}_{2} \mathrm{O}$ samples should be taken in the shortest time possible to observe a measurable increase in $\mathrm{N}_{2} \mathrm{O}$ headspace concentration. Rochette and Eriksen-Hamel (2008) estimated that incubation periods greater than 40 min are likely to result in significant negative impacts on chamber conditions. To assess $\mathrm{N}_{2} \mathrm{O}$ emissions in sugarcane fields, it is recommended an incubation period of $20 \mathrm{~min}$, in which four samples should be collected. Initial headspace gas samples will be collected using 20-ml nylon syringes at the beginning of the incubation and, as guidance, at 5, 10 and 20 min thereafter (Feigl et al., 1995; Carvalho et al., 2009). The collected samples will be transferred to sealed pre-evacuated vials.

In GHG sampling and storage, it is recommended to use pressurized containers (vials, exetainers and vacutainers). Is not advised to store $\mathrm{N}_{2} \mathrm{O}$ samples using syringes (plastic or glass syringes). During the sampling period, it is advisable to collect samples of standard gas (average concentration known) to analyze the reliability of $\mathrm{N}_{2} \mathrm{O}$ storage system. In order to analyze the gas fluxes, samples inside the vials should be injected into the gas chromatograph.

The headspace temperature during $\mathrm{N}_{2} \mathrm{O}$ sampling in the field is rarely the same as laboratory temperature at the time of air sample analysis (Rochette and Hutchinson, 2005). Thus, the temperature based on the perfect gas law should be corrected. Atmospheric pressure, soil temperature and soil moisture measurements should be performed during the gas sampling. Samples should be stored in vials and the maximum duration of sample storage would be 30 days.

The time assessment of $\mathrm{N}_{2} \mathrm{O}$ fluxes in sugarcane areas will be dependent on the $\mathrm{N}$ source applied to the soil, such as $\mathrm{N}$ fertilizer, vinasse, filter cake and straw/ litter from harvesting. As an indicative guidance, for the $\mathrm{N}$ fertilizer and vinasse application, the sampling period could be daily for the first 15 days and then every three days for the next 15 days. For the application of filter cake, the sampling period should be daily for the first 15 days and then every three days for the next 75 days, totaling 90 days. The $\mathrm{N}_{2} \mathrm{O}$ emission arising from the straw deposition on soil should be performed during one year, on a daily basis for the first 15 days and every seven days until the end of period.

\section{Greenhouse Gas Analyses}

Gas chromatograph can be used to analyze GHG concentrations: Electron Capture Detector $\left({ }^{63} \mathrm{Ni}\right)$ operated at $230{ }^{\circ} \mathrm{C}$ to determine concentrations of $\mathrm{CO}_{2}$ and $\mathrm{N}_{2} \mathrm{O}$ and Flame Ionization Detector (FID) to quantify the $\mathrm{CH}_{4}$ concentration in the same sample. Certified gases (parts per million in volume) are used as standards. Then, fluxes are calculated on the basis of the linear change in the gas concentration collected from the chamber during the incubation period. Alternatively to the static chambers, when possible, the eddy covariance technique can be used to measure fluxes on a quasi-continuous basis. The principle of this micrometeorological approach is that the exchange rate of a trace gas (flux) across the interface of the atmosphere and a plant canopy can be calculated as the covariance between fluctuations of vertical wind velocity and this gas (Baldocchi, 2003).

\section{Expression of results}

$\mathrm{N}_{2} \mathrm{O}$ fluxes are calculated from the increment in concentration during the incubation period when the chamber is attached to the base and expressed as arithmetic means with standard deviation. Cumulative fluxes are calculated by plotting daily fluxes through time, interpolating linearly between them and integrating the area under the curve (Jantalia et al., 2008). With accumulated emissions, it is possible to calculate $\mathrm{N}_{2} \mathrm{O}$ emission factors that represent the percentage of $\mathrm{N}$ added that is lost to atmosphere as $\mathrm{N}_{2} \mathrm{O}$. The emission factor (EF) can be calculated by the following equation: $\mathrm{EF}=$ (kg N-N $\mathrm{N}_{2} \mathrm{O}$ emitted / kg N added) × 100 .

\section{Final Remarks}

Conventional life cycle accounting (used to estimate the net offset value of biofuels) focuses largely on emissions 'at the factory gate', associated with the processing and production facility and on the end use of the product. Generally, they employ only generic estimates for emissions 'at the farm gate' associated with the production of biofuel feedstocks, i.e., grain, crop residues, grasses. However, a major determinant of the overall greenhouse gas offset value of many biofuels is in fact the land management practices (e.g. crop selection, tillage, fertilizer management) and environmental factors (climate, soil type) that are associated with the production of the feedstock (i.e. emissions at the farm-gate). For example, soil C sequestration, in perennial grass biofuel crops, may constitute a significant portion of the net GHG offset achieved. For crop residues such as sugarcane litter, tillage management plays a major role in the net GHG value of the biofuel and the impacts on soil erosion.

Nitrogen management, as well as soil and climate variables, impact $\mathrm{N}_{2} \mathrm{O}$ emissions associated with intensive biofuel production. Consequently, these field-level components of the net emission profile for a particular biofuel vary for individual producers, according to their management, and they vary as a function of site-specific 
soil and climate conditions. Therefore, the present text is a piece of contribution that may help to obtain data not only on soil C stocks but also on GHG emissions in order to provide an accurate 'field-to-wheels' assessment. Given that the GHG offset value is the primary measure of biofuel product quality, biorefiners that can show a higher GHG offset of their product will have an advantage in the market place.

\section{References}

Baldocchi, D.D. 2003. Assessing ecosystem carbon balance: problems and prospects of the eddy covariance technique. Global Change Biology 9: 479-492.

Beddington, J.R.; Asaduzzaman, M.; Clark, M.E.; Fernandez Bremauntz, A.; Guillou, M.D.; Howlett, D.J.B.; Jahn, M.M.; Lin, E.; Mamo, T.; Negra, C.; Nobre, C.A.; Scholes, R.J.; van Bo, N.; Wakhungu, J. 2012. What next for agriculture after Durban? Science 335: 289-290.

Benites, V.M.; Machado, P.L.O.A.; Fidalgo, E.C.C.; Coelho, M.R.; Madari, B.E. 2007. Pedotransfer functions for estimating soil bulk density from existing soil survey reports in Brazil. Geoderma 139: 90-97.

Cançado, J.E.D.; Saldiva, P.H.N.; Pereira, L.A.A.; Lara, L.B.L.S.; Artaxo, P.; Martinelli, L.A.; Arbex, M.A.; Zanobetti, A.; Braga, A.L.F. 2006. The impact of sugar cane burning emissions on the respiratory system of children and the elderly. Environmental Health Perspectives 114: 725-729.

Carvalho, J.L.N.; Cerri, C.E.P.; Feigl, B.J.; Picollo, M.C.; Godinho, V.P.; Cerri, C.C. 2009. Carbon sequestration in agricultural soils in the Cerrado region of the Brazilian Amazon. Soil \& Tillage Research 103: 342-349.

Chapuis-Lardy, L.; Wrage, N.; Metay, A.; Chotte, J.; Bernoux, M. 2007. Soils, a sink for $\mathrm{N}_{2} \mathrm{O}$ ? A review. Global Change Biology 13: 1-17.

Crasswell, E.T.; Lefroy, R.D.B. 2001. The role and function of organic matter in tropical soils. Nutrient Cycling Agroecosystems 61: 7-18.

Davidson, E.A.; Araujo, A.C.; Artaxo, P.; Balch, J.K.; Brown, I.F.; Bustamante, M.M.C.; Coe, M.T.; DeFries, R.S.; Keller, M.; Longo, M.; Munger, J.W.; Schroeder, W.; Soares-Filho, B.S.; Souza Jr, C.M.; Wofsy, S.C. 2012. The Amazon basin in transition. Nature 481: 321-328.

Denman, K.L.; Brasseur, G.; Chidthaisong, A.; Ciais, P.; Cox, P.M.; Dickinson, R.E.; Hauglustaine, D.; Heinze, C.; Holland, E.; Jacob, D.; Lohmann, U.; Ramachandran, S.; da Siva Dias, P.L.; Wofsy, S.C.; Zhang, X. 2007. Couplings between changes in the climate system and biogeochemistry. p. 499-587. In: Solomon, S.; Qin, D.; Manning, M.; Chen, Z.; Marquis, M.; Averyt, K.B.; Tignor, M.; Miller, H.L., eds. Climate change 2007: the physical science basis; Contribution of Working Group 1 to the Fourth Assessment Report of the Intergovernmental Panel on Climate Change. Cambridge University Press, Cambridge, UK.

Denmead, O.T.; Macdonald, B.C.T.; Naylor, T.; Wang, W.; Salter, B.; White, I.; Wilson, S.; Griffith, D.W.T.; Moody, P. 2008. Whole-of-season greenhouse gas emissions from Australian sugarcane soils. Proceedings of the Australian Society of Sugar Cane Technologists 30: 105-113.
Dobbie, K.E.; Smith, K.A. 2003. Impact of different forms of N fertilizer on $\mathrm{N}_{2} \mathrm{O}$ emissions from intensive grassland. Nutrient Cycling Agroecosystems 67: 37-46.

Ellert, B.H.; Bettany, J.R. 1996. Calculation of organic matter and nutrients stored in soils under contrasting management regimes. Canadian Journal of Soil Science 75: 529-538.

FAOSTAT. 2012. FAO Statistical databases. Available at: http:// faostat.fao.org/site/340/default.aspx. [Accessed Jul. 22, 2012]

Feigl, B.J.; Steudler, P.A.; Cerri, C.C. 1995. Effects of pasture introduction on soil $\mathrm{CO}_{2}$ emissions during the dry season in the state of Rondônia, Brazil. Biogeochemistry 31: 1-14.

Foley, J.A.; Ramankutty, N.; Brauman, K.A.; Cassidy, E.S.; Gerber, J.S.; Johnston, M.; Mueller, N.D.; O'Connell, C.; Ray, D.K.; West, P.C.; Balzer, C.; Bennett, E.M.; Carpenter, S.R.; Hill, J.; Monfreda, C.; Polasky, S.; Rockstro, J.; Sheehan, J.; Siebert, S.; Tilman, D.; Zaks, D.P.M. 2011. Solutions for a cultivated planet. Nature 478: 337-342.

Forster, P.; Ramaswamy, V.; Artaxo, P.; Bernsten, T.; Betts, R.; Fahey, D.W.; Hay wood, J.; Lean, J.; Lowe, D.C.; Myhre, G.; Nganga, J.; Prinn, R.; Raga, G.; Schutz, M.; van Dorland, R. 2007. Changes in atmospheric constituents and in radiative forcing. p. 499-587. In: Solomon, S.; Qin, D.; Manning, M.; Chen, Z.; Marquis, M.; Averyt, K.B.; Tignor, M.; Miller, H.L., eds. Climate change 2007: the physical science basis; Contribution of Working Group 1 to the Fourth Assessment Report of the Intergovernmental Panel on Climate Change. Cambridge University Press, Cambridge, UK.

Gifford, R.M.; Roderick, M.L. 2003. Soil carbon stocks and bulk density: Spatial or cumulative mass coordinates as a basis of expression? Global Change Biology 9: 1507-1514.

Holland, E.A.; Robertson, G.P.; Greenberg, J.; Groffman, P.M.; Boone, R.D.; Gosz, J.R. 1999. Soil $\mathrm{CO}_{2}, \mathrm{~N}_{2}$ and $\mathrm{CH}_{4}$ exchange. $\mathrm{p}$. 185-201. In: Robertson, G.P., ed. Standard soil methods for long term ecological research. Oxford University Press, Oxford, UK.

Hoogwijk, M.; den Broek, R.; Berndes, G.; Faaij, A. 2001. A Review of Assessments on the Future of Global Contribution of Biomass Energy. James \& James, London, UK.

Hutchinson, G.L.; Livingston, G.P. 2002. Soil-atmosphere gas exchange. p. 1159-1182. In: Dane, J.H.; Topp, G.C., eds. Methods of soil analysis. Part 4. SSSA, Madison, WI, USA.

IPCC. 2006. IPCC Guidelines for National Greenhouse Gas Inventories. Volume 4, IGES, Hayama, Japan.

IPCC. 2007a. Climate change 2007: the physical science basis; Contribution of Working Group I to the 4th Assessment Report of the Intergovernmental Panel on Climate Change. Cambridge University Press, Cambridge, UK. 996p.

IPPC. 2007b. Climate change 2007: mitigation of climate change; Contribution of Working Group III to the the 4th Assessment Report of the Intergovernmental Panel on Climate Change. Cambridge University Press, Cambridge, UK. 532p.

International Organization for Standardization [ISO]. 2002a. ISO 10381-1: Soil Quality - Sampling. Part 1: Guidance on the Design of Sampling Programmes. International Organization for Standardization, Geneva, Switzerland.

International Organization for Standardization [ISO]. 2002b. ISO 10381-2: Soil Quality - Sampling. Part 2: Guidance on Sampling Techniques. International Organization for Standardization, Geneva, Switzerland. 
International Organization for Standardization [ISO]. 2003. ISO 10381-4: Soil Quality - Sampling. Part 4: Guidance on the Procedure for Investigation of Natural, Near-Natural and Cultivated Sites. International Organization for Standardization, Geneva, Switzerland.

Jantalia, C.P.; dos Santos, H.P.; Urquiaga, S.; Boddey, R.M.; Alves, B.J.R. 2008. Fluxes of nitrous oxide from soil under different crop rotations and tillage systems in the South of Brazil. Nutrient Cycling Agroecosystems 82: 161-173.

Knowles, R. 1982. Denitrification. Microbiology Review 46: 4370.

Kowalchuck, G.A.; Stephen, G.R. 2001. Ammonia-oxidising bacteria: a model for molecular microbial ecology. Annual Review Microbiology 55: 485-529.

Livingston, G.P.: Hutchinson, G.L. 1995. Enclosure-based measurement of trace gas exchange: Applications and sources of error. p. 14-51. In: Matson, P.A.; Harris, R.C., ed. Biogenic trace gases: measuring emissions from soil and water. Blackwell Science, Oxford, UK.

Ma, W.; Schautz, A.; Fishback, L.; Bedard-Haughn, A.; Farrell, R.; Siciliano, S. 2007. Assessing the potential of ammonia-oxidising bacteria to produce nitrous oxide in soils of a high arctic lowland ecosystem on Devon Island, Canada. Soil Biology \& Biochemistry 39: 2001-2013.

Macedo, I.C.; Nogueira, L.A.H. 2004. Assessment of ethanol production expansion in Brazil. Centro de Gestão e Estudos Estratégicos, Brasília, DF, Brazil (in Portuguese, with abstract in English).

McBratney, A.B.; Minasny, B. 2010. Comment on "Determining soil carbon stock changes: Simple bulk density corrections fail". Agriculture, Ecosystems and Environment 136: 185-186.

Mer, J.L.; Roger, P. 2001. Production, oxidation, emission and consumption of methane by soils: a review. European Journal of Soil Biology 37: 25-50.

Minasny, B.; McBratney, A.B.; Hong, S.Y.; Sulaeman, Y.; Kim, M.S.; Zhang, Y.S.; Kim, Y.H.; Han, K.H. 2012. Continuous rice cropping has been sequestering carbon in soils in Java and South Korea for the past 30 years. Global Biogeochemical Cycles 26, GB3027. DOI: http://dx.doi.org/10.1029/2012GB004406

Moraes, J.F.L.; Volkoff, B.; Cerri, C.C.; Bernoux, M. 1996. Soil properties under Amazon forest and changes due to pasture installation in Rondonia. Geoderma 70: 63-81.

Mosier, A.R.; Kroeze, C.; Nevison, C.; Oenema, O.; Seitzinger, S.; van Cleemput, O. 1998. Closing the global atmospheric $\mathrm{N}_{2} \mathrm{O}$ budget: nitrous oxide emissions through the agricultural nitrogen cycle. Nutrient Cycling Agroecosystems 52: 225-248.

Nelson, D.W.; Sommers, L.E. 1996. Total carbon, organic carbon, and organic matter. In: Page, A.L., ed. Methods of soil analysis. Part 2. 2ed. American Society of Agronomy, Madison, WI, USA.
Resende, A.S.; Xavier, R.P.; Oliveira, O.C.; Urquiaga, S.; Alves, B.Jr.; Boddey, R.M. 2006. Long-term effects of pre-harvest burning and nitrogen and vinasse applications on yield of sugar cane and soil carbon and nitrogen stocks on a plantation in Pernambuco, NE, Brazil. Plant and Soil 281: 339-351.

Rochette, P.; Bertrand, N. 2007. Soil-surface gas emissions. p. 851861. In: Carter, M.; Gregorich, E.G., eds. Soil sampling and methods of analysis. CRC Press, Boca Raton, FL, USA.

Rochette, P.; Eriksen-Hamel, N.S. 2008. Chamber measurements of soil nitrous flux: are absolute values reliable? Soil Science Society of America Journal 72: 331-342.

Rochette, P.; Hutchinson, G.L. 2005. Measurement of soil respiration in situ: chamber techniques. p. 247-286. In: Hatfield, J.L.; Baker, J.M., eds. Micrometeorology in agricultural systems. . SSSA, Madison, WI, USA. (Agronomy Monographs, 47).

Saggar, S.; Luo, J.; Giltrap, D.L.; Maddena, M. 2009. Nitrous oxide emissions from temperate grasslands: processes, measurements, modeling and mitigation. p. 1-66. In: Sheldon, A.I.; Barnhart, E.P., eds. Nitrous oxide emissions research progress. Nova Science, New York, NY, USA.

Saggar, S.; Harvey, M.J.; Singh, J.; Giltrap, D.L.; Pattey, E.; Bromley, A.M.; Dow, D.; Martin, R.J.; Moss, R.; McMillan, A.M.S. 2010. Chambers, micrometeorological measurements, and NZ-DNDC model for nitrous oxide emissions estimates from an irrigated dairy-grazed pasture. Journal of Integrative Environmental Sciences 7: 61-70.

Schmidt, M.W.; Torn, M.S.; Abiven, S.; Dittmar, T.; Guggenberger, G.; Janssens, I.A.; Kleber, M.; Kogel-Knabner, I.; Lehmann, J.; Manning, D.A.; Nannipieri, P.; Rasse, D.P.; Weiner, S.; Trumbore, S.E. 2011. Persistence of soil organic matter as an ecosystem propoerty. Nature 478: 49-56.

Schumacher, B.A. 2002. Methods for the determination of total organic carbon (TOC) in soils and sediments. US. Environmental Protection Agency, Washington, DC, USA. 25p.

Smith, K.A.; Conen, F. 2004. Measurement of trace gases: gas analysis, chamber methods, and related procedures. p. 433437. In: Smith, K.A.; Cresser, M.C., eds. Soil and environmental analysis: modern instrumental techniques. Marcel Dekker, New York, USA.

Walkley, A.; Black, I.A. 1934. An examination of the Degtjareff method for determining soil organic matter and a proposed modification of the chromic acid titration method. Soil Science 37: 29-38.

Wrage, N.; Velthof, G.L.; van Beusichem, M.L.; Oenema, O. 2001. Role of nitrifier denitrification in the production of nitrous oxide. Soil Biology \& Biochemistry 33: 1723-1732. 